University of Nebraska - Lincoln

DigitalCommons@University of Nebraska - Lincoln

Faculty Papers and Publications in Animal

Science

Animal Science Department

2005

Phosphorus and Dairy/Beef Nutrition

\author{
Larry D. Satter \\ USDA -ARS \\ Terry J. Klopfenstein \\ University of Nebraska-Lincoln, tklopfenstein1@unl.edu \\ Galen E. Erickson \\ University of Nebraska-Lincoln, gerickson4@unl.edu \\ J. Mark Powell \\ USDA-ARS, mark.powell@wisc.edu
}

Follow this and additional works at: https://digitalcommons.unl.edu/animalscifacpub

Part of the Animal Sciences Commons

Satter, Larry D.; Klopfenstein, Terry J.; Erickson, Galen E.; and Powell, J. Mark, "Phosphorus and Dairy/Beef Nutrition" (2005). Faculty Papers and Publications in Animal Science. 549.

https://digitalcommons.unl.edu/animalscifacpub/549

This Article is brought to you for free and open access by the Animal Science Department at DigitalCommons@University of Nebraska - Lincoln. It has been accepted for inclusion in Faculty Papers and Publications in Animal Science by an authorized administrator of DigitalCommons@University of Nebraska - Lincoln. 


\title{
Phosphorus and Dairy/Beef Nutrition
}

\author{
LARRY D. SATTER \\ U.S. Dairy Forage Research Center \\ USDA-ARS \\ Madison, Wisconsin
}

\section{TERRY J. KLOPFENSTEIN AND GALEN E. ERICKSON}

University of Nebraska

Lincoln, Nebraska

\section{J. MARK POWELL}

\author{
U.S. Dairy Forage Research Center \\ USDA-ARS \\ Madison, Wisconsin
}

Phosphorus (P), a required nutrient for all livestock, has numerous essential physiological functions in the body that include energy transfer (ATP), structure of bone, teeth, and membranes, and buffering $\mathrm{pH}$ changes in the rumen (salivary phosphate). Ruminants use a larger proportion of dietary $\mathrm{P}$ than nonruminants because rumen microbes produce phytase, the enzyme that hydrolyzes $\mathbf{P}$ from phytate. The majority of $\mathrm{P}$ in most grains is in phytate form, a $\mathbf{P}$ form largely unavailable to swine and poultry.

Feedstuffs vary greatly in total $\mathrm{P}$ content, ranging from about $0.1 \%$ in corn (Zea mays L.) stalks and winter pasture to 0.6 to $1.0 \%$ in protein supplements and some by-product feeds. In general, grains contain more $\mathrm{P}$ than forages, and high protein feeds contain more $\mathrm{P}$ than low protein feeds. Feedstuffs grown on soils deficient in P tend to have lower P content than those grown on P-rich soils. Phosphorus frequently has been added to forage and grain-based ruminant diets in the form of mineral supplements, such as dicalcium phosphate, monosodium phosphate, phosphoric acid, or bone meal. Phosphorus is a costly mineral supplement, and is typically the second or third most costly of all diet supplements, following energy (grain) and protein supplements.

The $\mathrm{P}$ content of ruminant diets has tended to increase over time as the amount of grain, protein supplement, and by-products fed to beef and dairy cattle has increased. Production of higher quality forages on P-enriched soils has also contributed to higher $P$ content of some ruminant diets. Given the important role of $P$ in eutrophication of lakes and streams, and the significant cost of adding a $P$

Copyright $\odot$ 2005. American Society of Agronomy, Crop Science Society of America, Soil Science Society of America, 677 S. Segoe Rd., Madison, WI 53711, USA. Phosphorus: Agriculture and the Environment, Agronomy Monograph no. 46. 
supplement to the ruminant diet, it is important that dietary $\mathrm{P}$ not exceed the animals' requirement. Unfortunately, $P$ content of dairy and feedlot cattle diets is often in excess of the animals' requirement. The objective of this chapter is to explore the nature of excessive $P$ in the ruminant diet and its significance to our environment.

\section{ROLE OF PHOSPHORUS IN THE RUMINANT'S BODY}

About $80 \%$ of the $\mathrm{P}$ in a ruminant's body is found in bones and teeth. The remaining $20 \%$ actively participates in numerous functions throughout the body (Breves and Schroder, 1991). Less than $1 \%$ of body $\mathrm{P}$ is in blood. Inorganic phosphorus $\left(\mathrm{P}_{\mathrm{i}}\right)$ content of blood serum is usually maintained at 1.3 to $2.6 \mathrm{mM}$. Blood serum concentrations of $1.3 \mathrm{mM} \mathrm{P}_{\mathrm{i}}$ can be indicative of $\mathrm{P}$ deficiency, but plasma concentrations alone are not always a reliable indicator of a ruminant's $P$ status.

Ruminants and nonruminants differ somewhat in $\mathrm{P}$ metabolism. Large amounts of inorganic $P$ are secreted into the gastrointestinal tract of ruminants via saliva because phosphate is a crucial buffer for ruminal fermentation. Salivary $P$ is largely reabsorbed from the small intestine into the body, and becomes available again for secretion as salivary phosphate. Cows will secrete 30 to $60 \mathrm{~g}$ salivary $\mathrm{P} \mathrm{d}^{-1}$ into the rumen (Breves and Schroder, 1991), an amount equal to 50 to $75 \%$ of daily $P$ intake. Small amounts of $P$ are secreted into the gut with gastric and pancreatic juice, bile and intestinal fluid, but these contributions are small, and there is no evidence that ruminants differ significantly from nonruminants relative to these secretions.

The small intestine is the major site for $\mathrm{P}$ absorption from the gut. Transport across the gut consists of both an active saturable and a passive nonsaturable component (Breves and Schroder, 1991). Vitamin D (1,25-dihydroxyvitamin D) is essential for the active portion of $\mathrm{P}$ transport. In addition, parathyroid hormone and calcitonin participate in regulating $\mathrm{P}$ absorption and $\mathrm{P}$ homeostatis. Passive absorption is the predominant mechanism when medium to high amounts of absorbable $\mathrm{P}$ are consumed.

In nonruminants, significant amounts of $P$ are excreted in urine, as well as in feces. In ruminants, normally $>95 \%$ of the $\mathrm{P}$ is excreted in feces, with perhaps 25 to $50 \%$ of fecal P contained in microbial residues originating from gut fermentation activity (Wu et al., 2000). With high dietary P, however, some animals will excrete more $P$ in urine (Wu et al., 2001). Also, high concentrate diets, typical of those fed to feedlot cattle, can result in elevated urinary $\mathbf{P}$ concentrations (Ternouth, 1990), and in some cases urinary excretion of $P$ can equal fecal excretion (Reed et al., 1965)

Bone is an important reservoir for $\mathrm{P}$ in the body, and as much as $30 \%$ of bone $\mathrm{P}$ can be mobilized in lactating beef cows to meet $\mathrm{P}$ need in early lactation (Ternouth, 1990). Based on this estimate for beef cows, a dairy cow weighing 600 $\mathrm{kg}$ could mobilize approximately $1000 \mathrm{~g}$ of bone $\mathrm{P}$ in early lactation. Phosphorus mobilized from bone would need to be restored in later lactation, but the sizeable bone reserve provides a buffer against short-term $P$ deficiencies. 
Rumen microbes require $\mathrm{P}$ and obtain it from the $\mathrm{P}$ released during fermentation of feed in the rumen, and from salivary P. Durand and Kawashima (1980) suggested the maximum $P$ requirement for ruminal microbes is satisfied when the diet contains $4 \mathrm{~g} \mathrm{P} \mathrm{kg}^{-1}$ digestible organic matter. This is equivalent to $<0.30 \%$ dietary P. This is probably a high estimate, however, because in vitro rumen studies suggest that $\mathrm{P}$ concentrations in ruminal fluid of 0.7 to $2.6 \mathrm{~m} M$ (Breves and Schroder, 1991) are adequate to support maximum microbial growth, and these concentrations can be achieved with diets containing as low as $0.12 \%$ P (NRC, 2001 ). This of course depends upon how much $P$ is contributed by saliva. Durand and Komisarczuk (1988) suggest that available $P$ from dietary sources and saliva be at least $5 \mathrm{~g} \mathrm{~kg}^{-1}$ digestible organic matter. If $P$ is fed to meet the animals' requirement, then there will be sufficient $P$ from salivary and feed sources to meet the requirement of rumen microbes.

\section{PHOSPHORUS REQUIREMENTS OF DAIRY COWS}

There has been much confusion about the $\mathrm{P}$ requirement of lactating dairy cows. This is reflected in large differences between feeding standards used by different countries in Europe and North America (Tamminga, 1992). Some standards differ by as much as threefold in their estimate of $\mathrm{P}$ maintenance requirements, and nearly twofold in the requirement for milk production. Likewise, large differences exist in estimates of $\mathbf{P}$ availability in the gut. However, the standards differ relatively little in their final recommendations for $P$ feeding, as extreme differences in maintenance and lactation requirements tend to offset each other. The $\mathrm{Na}$ tional Research Council (NRC) in the USA (NRC, 2001) presents an excellent summary of $\mathbf{P}$ utilization by dairy cows, and does much to clarify what has been unclear in the past.

The P requirement of lactating cows, as suggested by the NRC (2001), is equal to the sum required for maintenance, growth, pregnancy, and milk production. By definition, the maintenance requirement for $\mathrm{P}$ is the inevitable loss of $\mathrm{P}$ in feces and urine when dietary $P$ just meets the requirement. Most feeding standards have related the maintenance requirement to liveweight, but evidence suggests that it is more closely related to dry matter (DM) intake. One reason for the close relationship between $\mathrm{P}$ maintenance requirement and dry matter intake is that up to $50 \%$ of fecal $\mathrm{P}$ is in rumen microbial residues (Wu et al., 2000), and the microbial mass is directly related to fermentable energy intake or DM intake. The maintenance requirement for absorbed $\mathrm{P}$ is $1.0 \mathrm{~g} \mathrm{~kg}^{-1} \mathrm{DM}$ intake, plus an additional $0.002 \mathrm{~g} \mathrm{~kg}^{-1}$ bodyweight for $P$ inevitably excreted in urine.

The requirement of absorbed $\mathrm{P}$ for growth is equal to the $\mathrm{P}$ deposited in the body during growth. An allometric equation developed by the Agricultural and Food Research Council (1991) for growing cattle was used for the growth requirement in the NRC (2001) recommendations. The amount of absorbed P required daily is:

$$
\mathrm{P}\left(\mathrm{g} \mathrm{d}^{-1}\right)=\left(1.2+\left(4.635 \times \mathrm{MW}^{0.22}\right) \times\left(\mathrm{BW}^{-0.22}\right)\right) \times \mathrm{WG}
$$


where $\mathrm{MW}=$ expected mature liveweight $(\mathrm{kg}), \mathrm{BW}=$ current liveweight $(\mathrm{kg})$, and $\mathrm{WG}=$ weight gain $\left(\mathrm{kg} \mathrm{d}^{-1}\right)$.

For example, for cattle with a mature body weight of $681 \mathrm{~kg}$, the absorbed $P$ requirement ( $\mathrm{g} \mathrm{kg}^{-1}$ average daily gain) ranges from $8.3 \mathrm{~g}$ at $100 \mathrm{~kg}$ bodyweight to $6.2 \mathrm{~g}$ at $500 \mathrm{~kg}$.

The requirement for absorbed $P$ during pregnancy is insignificant until the last trimester. A cow requires $1.9 \mathrm{~g} \mathrm{P} \mathrm{d}^{-1}$ at $190 \mathrm{~d}$ of pregnancy, and this increases to $5.4 \mathrm{~g} \mathrm{~d}^{-1}$ at $280 \mathrm{~d}$. The requirement for absorbed $P$ for milk production equals the amount of $P$ secreted in milk. Milk containing 3.0 to $3.2 \%$ crude protein contains about $0.9 \mathrm{~g} \mathrm{P} \mathrm{kg}^{-1}$ milk. Approximately half of the $\mathrm{P}$ in milk is complexed with casein, so milk containing more protein also contains more P. Milk containing $4 \%$ crude protein contains about $1.04 \mathrm{~g} \mathrm{P} \mathrm{kg}^{-1}$ milk. Phosphorus content of milk is poorly related to milk fat content.

To relate the absorbed $P$ requirement to dietary $P$, the availability of $P$ in the gastrointestinal tract must be known. The estimates for $\mathrm{P}$ availability in the gastrointestinal tract are variable. The NRC (2001) suggests using the following $\mathrm{P}$ absorption coefficients: forages, $64 \%$; concentrates, $70 \%$; dicalcium phosphate, $75 \%$; bone meal, $80 \%$; and monosodium phosphate, $90 \%$. Recent research (Aguerre et al., 2002) indicates that $\mathrm{P}$ availability in concentrates may average $75 \%$ or higher, suggesting that the NRC estimates for $P$ requirements of lactating cows actually provides a moderate margin of safety. As mentioned earlier, phytate $P$, the main form of $P$ in most grains, is almost totally available to ruminants because of phytase production by rumen microbes.

Most lactating dairy cows can meet their $P$ requirement with diets containing 0.32 to $0.38 \% \mathrm{P}$ (DM basis). Dry cows need about 0.22 to $0.26 \%$ dietary $\mathrm{P}$. Many lactation diets formulated for high-producing cows contain 0.35 to $0.40 \% \mathrm{P}$ prior to $P$ supplementation.

Although the literature on $P$ utilization and $P$ requirements of lactating cows has been surprisingly consistent, the interpretation of published reports has caused much confusion. This confusion has led to feeding of unrealistically large amounts of $P$ in dairy diets. Several surveys (Sansinena et al., 1999; Bertrand et al., 1999; L.D. Satter, unpublished data, 1999) in the USA during 1999 indicated that dairy diets were formulated to contain approximately 0.45 to $0.50 \% \mathrm{P}$ (DM basis), an amount that is about $25 \%$ in excess of the recommended level of feeding. This oversupplementation of $P$ was costing the U.S. dairy industry about $\$ 100$ million annually, as well as increasing risk of environmental damage through $P$ runoff loss from manure-amended fields causing eutrophication of lakes and streams. Recent evidence suggests that dairy producers have started to reduce dietary levels of $P$, and that average $\mathrm{P}$ concentrations in dairy diets have dropped from about $0.48 \%$ to about 0.44 or $0.45 \%$. This is good progress, but it still is about 15 to $20 \%$ in excess of the recommendation. It appears that dairy producers in many countries tend to overfeed $\mathrm{P}$, but little information is available on actual $\mathrm{P}$-feeding practices. A recent survey (Powell et al., 2002) of Wisconsin dairy producers found that $85 \%$ of the producers were feeding $P$ in excess of the $\mathrm{NRC}$ recommendations for their level of milk production.

How have we come to this point of excessive $\mathbf{P}$ feeding? There are at least three factors that have played a role. Perhaps most significant is the notion that in- 
creasing dietary $\mathrm{P}$ improves reproductive performance. Studies in South Africa (Theiler and Green, 1932) demonstrated that supplementing bone meal to beef cows grazing dry season rangeland improved reproductive performance, as well as growth rates and survival rates. A widely cited field study in England (Hignett and Hignett, 1951) involving 802 dairy cows in 39 herds demonstrated that herds having the lowest dietary $\mathrm{P}$ also had the lowest first service conception rates. In both of these classic studies, dietary $P$ levels were much lower than current NRC (2001) recommendations, and probably provided insufficient $\mathbf{P}$ for maximum rumen microbial growth. Durand and Kawashima (1980) suggested the maximum $\mathrm{P}$ requirement for ruminal microbes is $4 \mathrm{~g} \mathrm{P} \mathrm{kg}^{-1}$ digestible organic matter in the diet, which is equivalent to $<.30 \%$ dietary P. Extremely low dietary P can inhibit microbial growth, leading to reduced protein and energy supply to the host animal. It is well known that energy and protein supply can influence reproductive performance. Modern dairy diets never approach the low dietary P concentrations that could impair microbial growth. There is no evidence that feeding $\mathrm{P}$ in excess of NRC (2001) requirements improves reproductive performance. A summary of 13 trials where reproductive performance of dairy cows fed different levels of $P$ was measured indicated no relationship between reproductive performance and dietary $P$ content (Satter and Wu, 2000). A recent study by Lopez et al. (2002) affirms that feeding $P$ in excess of NRC (2001) recommendations has no effect on reproductive performance in lactating cows. In this study a total of 267 Holstein cows were randomly assigned at calving to a control diet containing $0.37 \% \mathrm{P}$ (dry basis) or to a treatment diet containing $0.57 \% \mathrm{P}$. Cows were fitted with a radiotelemetric transmitter (Heatwatch $\mathrm{DDx}^{\circledR}$ ) and were bred to natural estrous from Day 50 to Day 100 and to synchronized estrous after Day 100 . Weekly ultrasonography was performed from Day 50 until pregnancy. Weekly blood samples were analyzed for progesterone $\left(\mathrm{P}_{4}\right)$ concentrations. Dietary $\mathrm{P}$ had no effect on any of the observed reproductive parameters, and no effect on milk production or milk composition. Table 19-1 contains a sampling of reproductive measurements from this study (Lopez et al., 2002).

Another factor contributing to the overfeeding of $P$ to dairy cows has been the absence of lactation trials showing the absolute minimum of $P$ required to support moderate to high levels of milk production. Without knowing the minimum dietary $\mathbf{P}$ needed to support milk production, arriving at a reasonable margin of safety in formulating diets becomes problematic. This uncertainty has led to large margins of safety and excessive $P$ in the dairy diet. Information now available shows that moderate to high-producing dairy cows (7700-13 $000 \mathrm{~kg}$ milk/lactation) exhibit the beginning signs of $\mathrm{P}$ deficiency following long-term feeding (1-3 lactations) of diets containing about $0.30 \% \mathrm{P}$ (Brintrup et al., 1993; Valk and Sebek, 1999; Wu et al., 2000; Wu et al., 2001).

A third factor contributing to overfeeding of $\mathrm{P}$ has been aggressive marketing of $P$ supplements. This probably has been less important than the first two factors mentioned.

Figure $19-1$ is a summary of the status of $P$ nutrition of lactating dairy cows producing $>9100 \mathrm{~kg}$ milk in $305 \mathrm{~d}$ lactation (modified from Wu et al., 2001). The minimum dietary $\mathbf{P}$ that is consistent with normal or near normal animal performance is $0.30 \%$. At this dietary concentration, symptoms of $\mathrm{P}$ deficiency, that is, 
Table 19-1. Reproductive measurements for lactating dairy cows fed two levels of dietary P (Lopez et al., 2002).

\begin{tabular}{|c|c|c|c|}
\hline \multirow[b]{2}{*}{ Reproductive measurement } & \multicolumn{2}{|c|}{ Dietary $P$ (\% of diet DM) } & \multirow{2}{*}{$\begin{array}{c}\text { Probability } \\
\text { value }\end{array}$} \\
\hline & 0.37 & 0.57 & \\
\hline Days to first $P_{4}$ increase $\dagger$ & 53 & 53 & 0.97 \\
\hline Days to first natural estrust & 68 & 67 & 0.87 \\
\hline Days to first service & 89 & 90 & 0.87 \\
\hline Conception rate at first insemination $\$, \%$ & 39.4 & 42.0 & 0.67 \\
\hline Overall conception rate at $30 \mathrm{~d}$ I, $\%$ & 34.3 & 38.0 & 0.35 \\
\hline Overall conception rate at $60 \mathrm{~d}, \%$ & 29.1 & 31.8 & 0.47 \\
\hline Pregnancies lost $(30$ to $60 \mathrm{~d}), \%$ & 15.2 & 16.2 & 0.83 \\
\hline Pregnancies lost after $60 \mathrm{~d}, \%$ & 6.0 & 5.4 & 0.87 \\
\hline Days open & 112 & 116 & 0.45 \\
\hline Services/conception\# & 2.9 & 2.6 & 0.35 \\
\hline
\end{tabular}

$\dagger$ First increase in progesterone concentration $>1 \mathrm{ng} \mathrm{mL}^{-1}$.

$\$$ First natural estrus detected by the Heatwatch system between 50 and $100 \mathrm{~d}$.

$\S$ Number of pregnancies detected at $30 \mathrm{~d}$ divided by the number of first services.

II Number of pregnancies detected at $30 \mathrm{~d}$ divided by the total number of services.

\# Total number of services divided by the number of pregnancies detected at $30 \mathrm{~d}$.

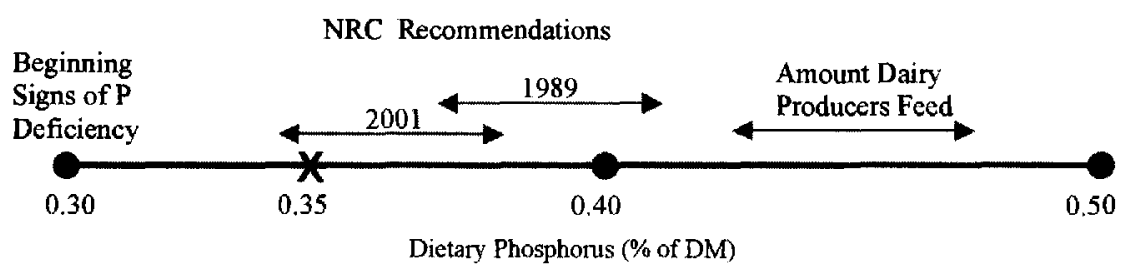

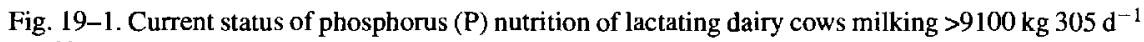
of lactation.

those primarily associated with a net loss of $P$ from bone, may begin to occur. At the other extreme of the continuum is what most dairy producers in the USA are actually feeding (Fig. 19-1). Levels of dietary $P<0.60 \%$ are not normally associated with signs of animal toxicity.

Figure 19-1 also shows the requirements for $\mathrm{P}$ as indicated by the NRC $(1989,2001)$. For ease of illustration, the NRC requirements are expressed in terms of $\% \mathrm{P}$ in the diet. This is based on dry matter intakes suggested by the NRC. The most recent NRC (2001) publication has lowered slightly the requirement for $P$ feeding, a change that is fully justified by research results. The NRC presents requirements, but does not include a margin of safety. In calculating the requirement, however, the NRC committee used a somewhat conservative estimate for $\mathrm{P}$ availability, or the $\mathrm{P}$ absorption coefficient. The NRC (2001) model used P absorption (availability) coefficients of 64 and $70 \%$ for forages and concentrates, respectively. Recent experiments on $\mathrm{P}$ availability in some common dairy feedstuffs suggest that true digestibility or availability is in the range of 70 to $85 \%$ (Aguerre et al., 2002). The long-term lactation studies mentioned earlier confirm that the NRC (2001) requirements are more than sufficient, and one might consider the NRC (2001) requirement to include a reasonable (approximately $10 \%$ ) margin of safety. 
A reasonable margin of safety with regard to $P$ feeding is difficult to determine. It depends upon uniformity of milk production of cows within the feeding group, variability of $P$ content of diet ingredients, and how quickly cows exhibit $P$ deficiency symptoms. The latter point refers to mobilization of $\mathrm{P}$ from bone, and the ability of bone to buffer short-term P deficiencies. Variability in DM intake between dairy cows of comparable milk production will also be a factor. The NRC (2001) suggests that Holstein cows weighing $680 \mathrm{~kg}$, having a body condition score of 3.0 (scale of $1-5$, where 5 is fat), that are 65 mo of age, and producing milk containing $3.5 \%$ fat and $3.0 \%$ true protein have a dietary requirement (using a sample diet) of $0.32,0.35,0.36$, and $0.38 \% \mathrm{P}$ for milk production amounts of 25 , 35,45 , and $55 \mathrm{~kg} \mathrm{~d}^{-1}$, respectively. Grouping cows by milk production level would enable a closer match between dietary $\mathrm{P}$ and $\mathrm{P}$ requirement.

Based on information in NRC (2001) feed composition tables, the coefficient of variation for $\mathrm{P}$ content within a feedstuff listed is about $15 \%$. The NRC (2001) tabular values for $\mathrm{P}$ content of feedstuffs are more accurate relative to the NRC (1989) tabular values, as the older NRC values for $P$ content were systematically lower than actual laboratory analysis (Berger, 1995). Cows lose both calcium (Ca) and P from bone to help supply these elements in early lactation. As pointed out earlier, Ternouth (1990) suggested that up to $30 \%$ of bone $P$ can be removed during early lactation. The mobilized bone $P$ reduces the need for elevated dietary P levels in the first weeks of lactation when feed intake lags behind milk production.

It is fairly common for dairy producers to split the herd into two or three groups according to milk production or stage of lactation, and formulate diets to meet the nutrient needs of each group. A reasonable approach to feeding $\mathrm{P}$ levels close to herd requirement might be to formulate group rations using NRC (2001) recommendations that match the average milk production level of the top $25 \%$ of cows in a feeding group. If this is done, then high production groups in the highest producing herds would meet their $P$ requirement with a reasonable margin of safety by feeding diets containing .36 to $.40 \%$ P. This amount of dietary P can be supplied with little or no use of inorganic $P$ supplements and represents a 15 to $20 \%$ reduction in P content of the average dairy diet fed in the USA in 2002.

How well does the literature support the NRC (2001) recommendations? Table 19-2 contains a summary of lactation studies where the control group was fed an amount of $P$ approximately equal to or below the requirement suggested by NRC (2001), and the treatment group received P that was approximately equal to or greater than the NRC recommendation. This series of studies indicate that feeding P in excess of the current NRC (2001) recommendations was without benefit in terms of milk production. The average milk production for the low $\mathrm{P}$ groups was $29.9 \mathrm{~kg} \mathrm{~d}^{-1}$, and for the high $P$ groups was $29.8 \mathrm{~kg} \mathrm{~d}^{-1}$.

Phosphorus fed in excess of requirement is excreted, with the vast majority appearing in the feces. Typically, high producing cows fed just enough $P$ to meet their requirement excrete 35 to $55 \mathrm{~g} \mathrm{P} \mathrm{d}^{-1}$ in feces and $<\mathrm{g} \mathrm{P} \mathrm{d}^{-1}$ in urine. Cows fed $\mathrm{P} 20$ to $30 \%$ in excess of their requirement may excrete 70 to $90 \mathrm{~g} \mathrm{P} \mathrm{d}^{-1}$ in feces and 3 to $5 \mathrm{~g} \mathrm{Pd}^{-1}$ in urine (Wu et al., 2000). Table 19-3 contains results from a lactation study where cows were fed diets containing $0.31,0.39$, or $0.47 \% \mathrm{P}$ for a $308 \mathrm{~d}$ lactation (Wu et al., 2001). Based on bone $\mathrm{P}$ and ash content, cows fed the 
Table 19-2. Milk production response to dietary phosphorus (P) level.

\begin{tabular}{|c|c|c|c|c|}
\hline \multirow[b]{2}{*}{ Study } & \multicolumn{2}{|c|}{$\begin{array}{c}\text { Dietary } \mathrm{P} \\
\text { Percent of diet dry matter }\end{array}$} & \multicolumn{2}{|c|}{$\begin{array}{l}\text { Milk production } \\
\mathrm{kg} \mathrm{d}^{-1}\end{array}$} \\
\hline & LoP & Hi P & Lo P & Hi P \\
\hline $\begin{array}{l}\text { Kincaid et al. (1981) } \\
(20 \text { cows/trt })(10 \text { mo trial })\end{array}$ & 0.30 & 0.54 & 28.0 & 30.0 \\
\hline $\begin{array}{l}\text { Brintrup et al. (1993) } \\
(26 \text { cows/trt })(2 \text { complete lactations })\end{array}$ & 0.33 & 0.39 & 25.4 & 24.5 \\
\hline $\begin{array}{l}\text { Satter and Dhiman (1996) } \\
(23 \text { cows/trt })(12 \text { wk mid-lactation })\end{array}$ & 0.39 & 0.65 & 23.9 & 24.4 \\
\hline \multicolumn{5}{|l|}{ Valk and Sebek (1999) } \\
\hline Year $2(6-8$ cows/trt $)($ wk $2-31)$ & 0.28 & 0.34 & 34.1 & 33.1 \\
\hline $\begin{array}{l}\text { Wu et al. }(2000) \\
(9 \text { cows/trt)(complete lactation) }\end{array}$ & 0.40 & 0.49 & 36.5 & 36.2 \\
\hline \multicolumn{5}{|l|}{ Wu and Satter $(2000)$} \\
\hline Year 1 (21 cows/ttt)(complete lactation) & $0.31-0.38$ & $0.44-0.48 \dagger$ & 29.6 & 28.8 \\
\hline Year $2(26$ cows/trt $)($ complete lactation $)$ & $0.31-0.38 \dagger$ & $0.44-0.48 \dagger$ & 32.0 & 32.1 \\
\hline $\begin{array}{l}\text { Lopez et al. (2002) } \\
\text { (123 cows/trt)(first } 23 \mathrm{wk} \text { of lactation) }\end{array}$ & 0.37 & 0.57 & 35.1 & 34.9 \\
\hline Average & 0.34 & 0.47 & 29.9 & 29.8 \\
\hline
\end{tabular}

† Phosphorus content was 0.38 and $0.48 \%$ during confinement feeding for approximately two-thirds of the lactation, and 0.31 and $0.44 \%$ during grazing for the remainder of lactation for the low and high $\mathbf{P}$ diets, respectively.

Table 19-3. Performance of cows fed diets differing in phosphorus $(\mathrm{P})$ content for an entire lactation (Wu et al., 2001).

\begin{tabular}{lccc}
\hline & \multicolumn{3}{c}{ Dietary P (\% of dry matter) } \\
\cline { 2 - 4 } Item & 0.31 & 0.39 & 0.47 \\
\hline Number of cows & 10 & 14 & 13 \\
Dry matter intake, $\mathrm{kg} \mathrm{d}^{-1}$ & 25.0 & 25.0 & 24.6 \\
Milk, kg 308 d & 13038 & 11909 & 12126 \\
Milk fat, \% & 3.64 & 3.50 & 3.64 \\
Milk protein, \% & 3.16 & 3.13 & 3.10 \\
P intake, g d & 77.5 & 97.5 & 115.6 \\
Fecal P excretion, $\mathrm{g} \mathrm{d}^{-1}+$ & 43 & 66 & 88 \\
\hline
\end{tabular}

Fstimated using $68 \%$ as the diet DM digestibility, and the means for DMI and fecal $P$ concentrations $(.538, .829$, and $1.12 \%$ for the three treatments, respectively).

$0.31 \% \mathrm{P}$ diet were marginally deficient. Phosphorus fed in excess of the requirement, which in this example was close to $0.31 \%$, was excreted. Referring to Fig. 19-1, reducing $P$ content of dairy diets from 0.44 to 0.45 to 0.36 to $.40 \%$ represents a 15 to $20 \%$ reduction in dietary $P$, and a 20 to $25 \%$ reduction in manure $P$.

The dairy industry uses large amounts of by-product feeds, many of which serve as important sources of protein in the dairy diet. There is a tendency for feedstuffs that are high in protein content to also contain high concentrations of $P$, but there are significant deviations from this generalization. Table 19-4 shows the N/P ratio of common dairy supplements that are often brought into the ration because 
Table 19-4. Protein and phosphorus (P) content of some common dairy feedstuffs (NRC, 2001).

\begin{tabular}{lcccr}
\hline Feed & $\begin{array}{c}\text { Protein content } \\
\% \text { of DM } \dagger\end{array}$ & $\begin{array}{c}\text { N content } \\
\text { \% of DM }\end{array}$ & $\begin{array}{c}\text { Phosphorus content } \\
\text { \% of DM }\end{array}$ & N/P \\
\hline Bloodmeal $\dagger$ & 95.5 & 15.3 & 0.30 & 51.0 \\
Soybean meal $(48 \% \mathrm{CP}$ ) & 49.9 & 8.0 & 0.70 & 11.4 \\
Soybean (roasted) & 43.0 & 6.9 & 0.64 & 10.8 \\
Brewer's grains & 29.2 & 4.7 & 0.67 & 7.0 \\
Cottonseed & 23.5 & 3.8 & 0.60 & 6.3 \\
Corn distillers grains & 29.7 & 4.8 & 0.83 & 5.8 \\
Canola meal & 37.8 & 6.0 & 1.10 & 5.5 \\
Corn gluten feed & 23.8 & 3.8 & 1.00 & 3.8 \\
Wheat midds & 18.5 & 3.0 & 1.02 & 2.9 \\
Wheat bran & 17.3 & 2.8 & 1.18 & 2.4 \\
Meat and bone meal $¥$ & 54.2 & 8.7 & 4.73 & 1.8 \\
\hline
\end{tabular}

$\uparrow \mathrm{DM}=$ dry matter, $\mathrm{N}=$ nitrogen, $\mathrm{CP}=$ crude protein.

$\ddagger$ Porcine origin.

of their protein content. Bloodmeal and meat and bone meal (porcine) represent the extremes in this table. Both feedstuffs are high in protein resistant to degradation in the rumen, but bloodmeal supplies a very large amount of protein per unit of P. Meat and bone meal, on the other hand, supplies relatively little protein per unit of $P$. For dairy producers having trouble managing $P$, choice of a protein supplement or by-product feed can be an important decision affecting $P$ management. A growing number of dairy producers have discontinued using inorganic $P$ supplements, but because they use large amounts of by-product feeds high in $\mathrm{P}$ concentration, overall dietary $\mathrm{P}$ content may still be excessive $(0.40-0.50 \%)$. When least-cost ration formulation programs are employed, it is important that they not give credit for $\mathrm{P}$ content of a feedstuff if the diet does not need $\mathrm{P}$. A significant part of the dollar value of meat and bone meal is associated with its $P$ content. If $P$ is not needed, then meat and bone meal should not be given credit for the $\mathrm{P}$ it contributes in excess of the requirement. In fact, a negative value might be appropriately assigned in some cases.

\section{PHOSPHORUS REQUIREMENTS OF BEEF CATTLE}

There are two basic types of beef production systems. The first is foragebased, and includes the beef cow herd and calves that are being raised. The cow herd is maintained largely on pasture, crop residues, or conserved forage, and the calves are grazed or fed harvested forages until slaughtered, or are diverted to feedlots prior to slaughter. Feedlots represent the second beef production system, a system that relies heavily on grain for 'finishing' cattle prior to slaughter. The first system involves marginal levels of $P$ input, and the latter typically involves dietary P concentrations well in excess of the animals' requirement.

As in dairy cows, the $\mathrm{P}$ requirement for beef cows is the sum of $\mathrm{P}$ needs for maintenance, growth, pregnancy, and lactation. The $P$ requirement for each of these functions is essentially the same for beef and dairy, however, there are small differences. These differences probably have more to do with the literature avail- 
able when the NRC (USA) developed the recommendation than biological differences between beef and dairy animals. The NRC dietary recommendations for beef were published in 1996, and the Agricultural and Food Research Council (AFRC) recommendations in 1991.

For maintenance the beef NRC publication (1996) suggests a requirement of $16 \mathrm{mg} \mathrm{P} \mathrm{kg}^{-1}$ body weight. For a $450 \mathrm{~kg}$ animal, this is equal to $7.2 \mathrm{~g} \mathrm{P} \mathrm{d}^{-1}$. The AFRC (1991) bases the maintenance requirement on DM intake, similar to what the dairy NRC (2001) does.

The predicted $\mathrm{P}$ requirement for growth is calculated as $3.9 \mathrm{~g} \mathrm{P}$ for every 100 $\mathrm{g}$ of retained protein (NRC, 1996). Calculated retained protein for feedlot cattle gaining between 1.5 to $2.2 \mathrm{~kg} \mathrm{~d}^{-1}$ is approximately 150 to $220 \mathrm{~g} \mathrm{~d}^{-1}$. As liveweight gain increases, so does the amount of $P$ required. The requirement for gain is based on an experiment conducted by Ellenberger et al. (1950) where 129 entire carcasses from the fetus through $12 \mathrm{yr}$ of age were analyzed for P. Phosphorus retention was estimated from these whole-body analyses to correlate $P$ with protein retained by these cattle (dairy breed). Using this approach to estimate $P$ requirement for growth, a steer gaining $1 \mathrm{~kg}$ of weight daily requires approximately to $7 \mathrm{~g}$ of absorbed $\mathrm{P} \mathrm{d}^{-1}$ for the growth part of the requirement. Using the AFRC (1991) approach for dairy cows, the absorbed P requirement for beef cattle ranges between 6.2 and $8.3 \mathrm{~g} \mathrm{~d}^{-1}$.

For pregnancy, the beef NRC (1996) assumes an absorbed P requirement of $7.6 \mathrm{~g} \mathrm{P} \mathrm{kg}^{-1}$ fetal weight at birth, and a birth weight of $35 \mathrm{~kg}$. This requirement is distributed over the last 3 mo of pregnancy. This is equivalent to about $3 \mathrm{~g} \mathrm{~d}^{-1}$ of absorbed $\mathrm{P}$ during the last trimester of pregnancy. For milk production, the beef NRC (1996) assumes a requirement of $0.95 \mathrm{~g}$ absorbed $\mathrm{P} \mathrm{kg}^{-1}$ of milk produced.

To convert absorbed P to dietary P, the beef NRC (1996) uses a true digestibility or availability value of $68 \%$ for $\mathrm{P}$ in forages and grains, whereas the AFRC (1991) and the dairy NRC (2001) use a true digestibility value of $64 \%$ for $\mathrm{P}$ in forages and $70 \%$ for $\mathrm{P}$ in grains. The total amount of $\mathrm{P}$ required in the diet of a feedlot steer using NRC (1996) recommendations is approximately 15 to $26 \mathrm{~g} \mathrm{~d}^{-1}$ for bodyweights between 300 and $600 \mathrm{~kg}$. This equates to 0.20 to $0.30 \%$ $P$ in diet dry matter for typical feedlot animals, assuming dry matter intake of 10 to $12 \mathrm{~kg} \mathrm{~d}^{-1}$.

There is some indication that the NRC (1996) recommendation for feedlot cattle is higher than necessary. Erickson et al. (1999) evaluated $\mathrm{P}$ requirements of yearling steers $\left(380 \mathrm{~kg}\right.$ ) with typical feedlot gains of $1.5 \mathrm{~kg} \mathrm{~d}^{-1}$ and concluded that the $P$ requirement was $<0.14 \%$ of diet DM, or $70 \%$ of the NRC (1996) recommendations. In another study with finishing feedlot calves weighing $265 \mathrm{~kg}$, Erickson et al. (2002) concluded that the P requirement for finishing calves is $<0.16 \%$ of ration dry matter, or $14.2 \mathrm{~g} \mathrm{~d}^{-1}$. Again, this is less than what the NRC suggests for this size of feedlot animal. Because virtually all feedlot diet formulations that contain much corn grain will exceed these low requirement levels, Erickson et al. (2002) suggest that determining the $P$ requirement for feedlot cattle is unimportant. What is important is to remove all supplemental $P$ from feedlot diets, because typical feed ingredients provide more than enough $P$ without $P$ supplementation. Supplementation of mineral $P$ in finishing diets is an unnecessary economic cost for beef feedlot producers and can have negative environmental im- 
pact. Reducing dietary $P$ to closely match the requirement would require the use of very low $P$ feed ingredients, which is neither practical nor cost effective.

An emerging issue in the USA is the increasing use in feedlot diets of byproduct feeds from ethanol plants. These feedstuffs contain two to three times more $\mathrm{P}$ than shelled corn. Inclusion of these high $\mathrm{P}$ feedstuffs further increases the surplus of $\mathrm{P}$ in feedlot diets. These high $\mathrm{P}$ by-product feeds are usually economical replacements for shelled corn, and producers have an economic incentive to use them. About all a feedlot operation can do to minimize adverse environmental impact from the high $P$ manure produced with such feed ingredients is to make sure that there is sufficient land upon which to spread manure, and to manage field application of manure in a way that minimizes $P$ loss in water runoff.

The daily $P$ requirement, as well as dietary $P$ supply, varies greatly during the year for a beef cow. Grazing during a period of good grass growth provides considerably more $\mathbf{P}$ than grazing winter pasture or corn stalks. Likewise, the requirement for $\mathrm{P}$ is considerably higher during lactation than after the calf is weaned. A comprehensive review of $\mathrm{P}$ nutrition of grazing cattle is available (Karn, 2001).

The beef NRC (1996) suggests a range of 0.11 to $0.24 \%$ dietary P (DM basis) to cover the $P$ needs of beef cows consuming a wide range of diet energy densities and producing between 5 and $14 \mathrm{~kg}$ of milk at peak production. The requirement is closer to $0.24 \% \mathrm{P}$ in early lactation, and to $0.11 \%$ in later lactation. Diets of high digestibility may require a little more $\mathrm{P}$ than low digestible diets because often less feed will be consumed with the highly digested feed. However, $\mathrm{P}$ availability is likely to be greater with the high digestible feedstuffs. The net effect of diet digestibility may be quite small. Dry matter intake is assumed to range between 9 and $15 \mathrm{~kg} \mathrm{cow}^{-1} \mathrm{~d}^{-1}$, depending upon size of the cow and level of milk production. One concern about diets containing less than about $0.25 \% \mathrm{P}$ is the potential for not having sufficient $P$ for rumen microbes. High forage diets, typical of beef cow diets, stimulate saliva production and maximize recycling of $P$ to the rumen. More information is needed to clarify where low $\mathrm{P}$, high roughage diets may not be providing adequate $P$ for rumen microbes.

Animal performance and $P$ status were studied in two groups of 39 range cows (Angus $\times$ Hereford) over a 5-yr period in New Mexico (Judkins et al., 1985). One group had free access to salt alone (control), and the other to a mineral mix containing $50 \%$ dicalcium phosphate, $45 \%$ salt, and $5 \%$ cottonseed meal. The cows received no other mineral, protein, or energy supplements during the whole trial. Lack of P supplementation had a detrimental effect on cow performance only during $1 \mathrm{yr}$ of the experiment, which was a drought year. The combined effect of no $P$ supplementation and drought caused the nonsupplemented cows to calve later (7 April vs. 11 February) and wean lighter calves ( $226 \mathrm{vs} .253 \mathrm{~kg}$ ) than the P supplemented cows in the year following the drought. Percent calf crop did not differ between the two groups during 1 yr of the study. The authors concluded that rainfall (green plants have more $\mathrm{P}$ than dormant plants) or $\mathrm{P}$ supplementation before and during the breeding season may be critical in maintaining early calving date and heavier weaning weights. Other research (Little, 1980) has also shown that dietary $\mathrm{P}$ at approximately $65 \%$ of NRC recommendations results in no reduction in reproductive performance of beef females. 
A large experiment was conducted in Utah to determine the $P$ requirements for growth and reproduction of Hereford heifers (Call et al., 1978). Ninety-six 7-mo-old heifers were divided into two groups, with one fed a diet containing $0.14 \% \mathrm{P}$ (as fed basis), and the other group the same diet but supplemented with monosodium phosphate to give $0.36 \% \mathrm{P}$ (as fed basis). The experiment lasted $2 \mathrm{yr}$. The low $P$ diet provided about $66 \%$ of the NRC recommended level of $P$ and the high $\mathrm{P}$ diet about $174 \%$. The average daily weight gain was $450 \mathrm{~g} \mathrm{~d}^{-1}$ for both groups, and feed efficiency was similar for the two groups. The low $\mathrm{P}$ group had a 96\% pregnancy rate with $91 \%$ live calves, and the high P group had corresponding values of 100 and $93 \%$, respectively. These differences were not significant. After 9 mo on trial (approximately 16 mo of age), no differences were discernible in rib bone structure based on bone microradiographs. Although it appears that growing replacement heifers and mature beef cows have adequate $P$ nutrition during periods of active grass growth, $P$ deficiency can possibly develop when forage quality is low.

Reference was made earlier to the South African studies of Theiler and Green (1932), and how P supplementation improved performance of beef cows grazing dry season range. Clearly, with low quality forage, as in winter or dry season grazing of pastures or crop residues, $\mathrm{P}$ is often deficient. Phosphorus supplementation should be provided under these conditions of extremely low P intake. A free choice mixture of 50\% trace mineral salt and 50\% dicalcium phosphate is a practical method for supplementation under these conditions. Phosphorus is seldom an environmental issue with cow-calf operations, unless soil erosion is carrying P-laden soil particles from the pasture into streams and lakes. Phosphorus requirements of beef cows, and hence $P$ inputs, are low relative to dairy cows.

\section{DIETARY PHOSPHORUS AND THE ENVIRONMENT}

Recently passed federal legislation in the USA (USDA-NRCS, 2001) aims to reduce soil $\mathrm{P}$ buildup, loss, and pollution from animal operations by controlling manure management. Such regulations have been in effect for several years in The Netherlands, and an effort is being made throughout the European Economic Community to limit manure and fertilizer $P$ applications to amounts that are similar to crop uptake of P. The application of manure to cropland is becoming increasingly regulated based on a combination of manure $P$ content, soil test $P$ level, crop $P$ requirements, and a field's risk to lose runoff $P$ to surface water. At present, many beef and dairy operations would not be able to comply with these P-based regulations.

Growing beef animals and lactating dairy cows convert approximately 15 and $25 \%$ of dietary $P$ into carcass and milk P, respectively, and the rest goes into manure. Reducing dietary $P$ to requirement levels can greatly reduce manure $P$ excretions and the amount of land required to effectively use manure $\mathrm{P}$ (Table 19-5). For example, most dairy diets that are not supplemented with an inorganic $\mathrm{P}$ source contain 0.35 to $0.40 \%$ P. This of course depends upon the ration ingredients used. Because this concentration is similar to the $P$ requirement for lactating cows, it follows that essentially all of the supplemental $P$ fed above the require- 
Table 19-5. Amount of phosphorus (P) fed and excreted by a lactating cow producing $9090 \mathrm{~kg}$ milk in $305 \mathrm{~d}$, and the amount of land required to effectively use the manure $P$ (Powell et al., 2001).

\begin{tabular}{lcccc}
\hline $\begin{array}{l}\text { Dietary } \mathbf{P} \\
\text { concentration }\end{array}$ & $\begin{array}{c}\text { Estimated } \\
\text { supplemental } \mathbf{P}\end{array}$ & $\begin{array}{c}\text { Manure } \\
\mathbf{P}\end{array}$ & $\begin{array}{c}\text { Land area needed } \\
\text { to recycle manure }\end{array}$ & $\begin{array}{c}\text { Change in } \\
\text { land area }\end{array}$ \\
\hline$\%$ & kg lactation $^{-1}$ & kg lactation $^{-1}$ & ha & $\%$ \\
0.35 & 0 & 15.8 & 0.53 & Base \\
0.40 & 3.4 & 19.2 & 0.65 & 23 \\
0.48 & 8.9 & 24.7 & 0.81 & 53 \\
0.55 & 13.7 & 29.5 & 0.97 & 83 \\
\hline
\end{tabular}

$\dagger$ Assumptions: Cow is consuming average of $22.5 \mathrm{~kg}$ DM daily, and milk contains $0.09 \%$ P. There is no net change in $\mathbf{P}$ content of the cow. The cropping area is comprised of $37 \%$ corn for grain, $7 \%$ corn for silage, $47 \%$ alfalfa, and $9 \%$ soybean. Crop yields are typical for the Midwest, and crops remove $29.9 \mathrm{~kg} \mathrm{P} \mathrm{ha}^{-1} \mathrm{yr}^{-1}$. Manure application rate is based on crop $\mathrm{P}$ removal.

ment will be excreted in the manure. Assuming a crop uptake of $29.9 \mathrm{~kg} \mathrm{P} \mathrm{ha}^{-1}$, the requirement for land increases proportionally with the increase in manure $P$. Reducing dietary $\mathrm{P}$ to an amount that the lactating cow requires often means complete elimination of mineral $P$ supplements. It can also result in a major reduction in the amount of land required to effectively use manure $P$, and reduce $P$ buildup in fields. A recent survey (Powell et al., 2002) of $P$ feeding and manure nutrient recycling practices on Wisconsin dairy farms found that lowering dietary $P$ to levels recommended by NRC (2001) would reduce the number of farms having a positive $\mathrm{P}$ balance (manure $\mathrm{P}$ exceeds harvested crop $\mathrm{P}$ ) by $67 \%$ and the land area in positive $\mathrm{P}$ balance by $60 \%$.

The amount of dietary $P$ also affects the amount and form of $P$ in runoff from manure-amended fields. For example, when manure derived from dairy cows fed a high $(0.49 \%)$ and low $(0.31 \%) \mathrm{P}$ diet were applied at equal amounts, difference in $\mathrm{P}$ runoff between plots amended with manure from cows fed high dietary $\mathrm{P}$ was 8 to 10 times greater than from plots amended with manure from cows fed low dietary P (Fig. 19-2). When manure was applied at equivalent rates of P (40 kg $P \mathrm{~Pa}^{-1}$ ), the high $\mathbf{P}$ manure runoff concentrations and loads were approximately four to five times those of the low $\mathrm{P}$ manure. The higher soluble $\mathrm{P}$ in runoff from plots amended with the high $P$ manure at the same $P$ application rate suggests that the forms of $P$ in the manures were different. Excessive diet $P$ supplementation increases both total and water soluble P content of manure (Powell et al., 2001; Ebeling et al., 2002).

Another study on water solubility of manure P (Dou et al., 2002) measured water solubility of $P$ in manure obtained from cows fed different amounts of dietary P. Almost all of the P fed in excess of the cow's requirement ended up as water soluble $P$ in the manure. This is depicted in Fig. 19-3. Increasing dietary $P$ above the minimal requirement $(0.30 \% \mathrm{P}$ in Fig. $19-3)$ did not increase $\mathrm{P}$ secretion in milk. Dietary P in excess of the requirement was simply excreted in the manure, and largely in water soluble form. Clearly, reducing dietary P not only reduces $\mathrm{P}$ content of manure, but also greatly reduces the potential for runoff of soluble $\mathrm{P}$ from manure-amended fields.

In many areas of intensive livestock production the amount of $\mathrm{P}$ in manure often exceeds crop requirements. This can lead to a disposal rather than an agro- 


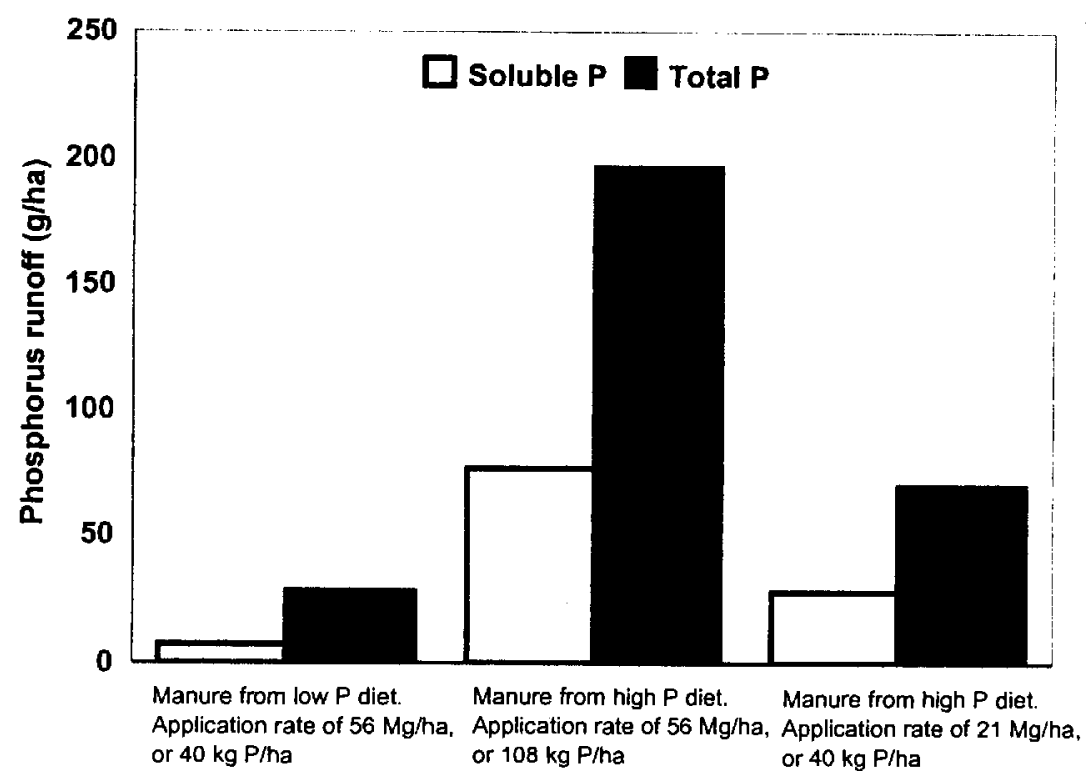

Fig. 19-2. Soil surface runoff of phosphorus (P) from plots amended with dairy manure derived from different dietary P levels (from Ebeling et al., 2002).

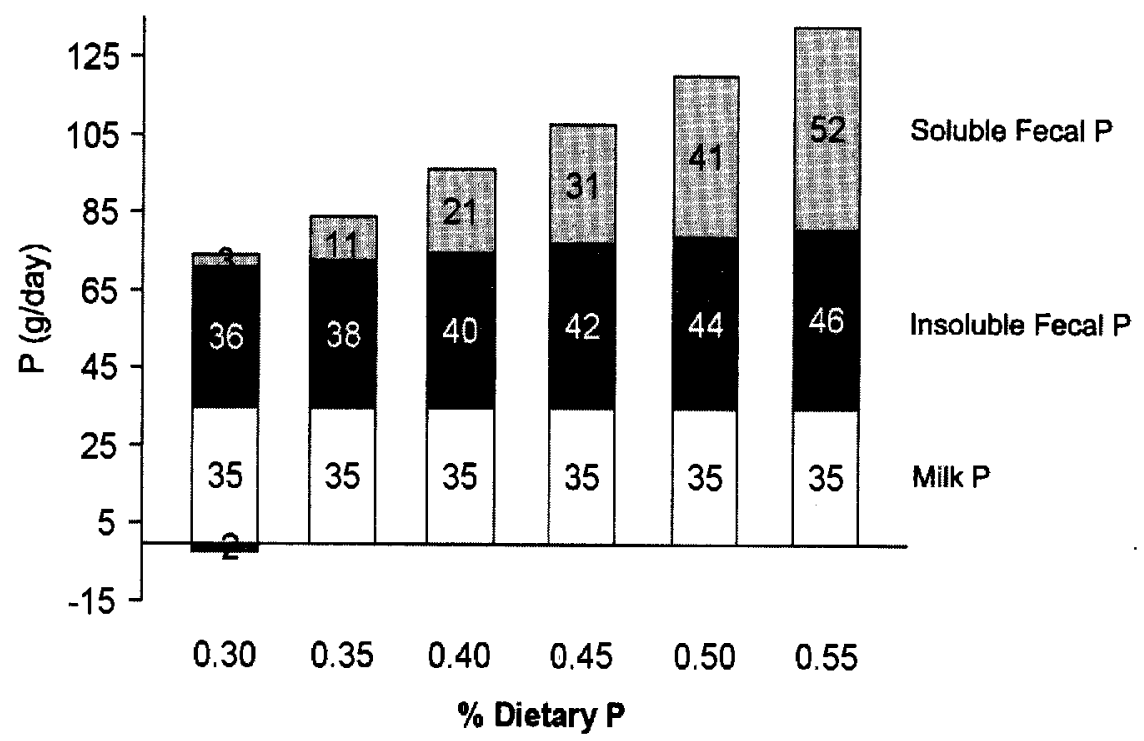

Fig. 19-3. Destination of dietary phosphorus in a dairy cow producing $38.6 \mathrm{~kg}$ milk and consuming 24 $\mathrm{kg}$ diet dry matter daily. Numbers within columns are amounts of $P\left(\mathrm{~g} \mathrm{~d}^{-1}\right)$ excreted as water-soluble fecal $P$, insoluble fecal $P$, or secreted as milk $P$; a small amount of mobilized bone $P\left(2 \mathrm{~g} \mathrm{~d}^{-1}\right)$ is depicted for the lowest dietary P level (developed from Ebeling et al., 2001; Dou et al., 2002; and Wu et al., 2001). 
nomic use of manure, with a subsequent build-up of soil test $P$ levels, much above what is needed for optimal crop yields. For example, most of the major dairy states in the USA have soil test $P$ levels that are in the high to above high categories (Fig. 19-4). In Wisconsin, soil test $\mathrm{P}$ (Bray-1 P extraction) have increased from an average of $34 \mathrm{mg} \mathrm{kg}^{-1}$ in the 1968 to 1973 period to $50 \mathrm{mg} \mathrm{kg}^{-1}$ in the 1990 to 1994 period (Bundy, 1998). An analysis of soil test P levels during the 1995 to 1999 period (Combs and Peters, 2000) showed that $75 \%$ of the soils tested above the "high" ( $\left.24 \mathrm{mg} \mathrm{kg}^{-1}\right)$ and $50 \%$ tested greater than the "excessively high" ( $\left.38 \mathrm{mg} \mathrm{kg}^{-1}\right)$ categories for most field crops grown on the prominent soils of the state (Kelling et al., 1998). Many dairy farms in Wisconsin have fields containing high or excessive levels of soil test $P$, and soil test $P$ is often very unevenly distributed within a field (Proost, 1999). Part of the rapid buildup of soil $P$ is due to surplus manure $P$ application.

Another example of overapplication of manure and excessive accumulation of soil $\mathrm{P}$ is in parts of the southern USA where broiler litter is spread on pastures grazed by beef cattle. In some areas, a beef cow-calf operation often includes broiler production. Broiler litter is effective in building pasture fertility and soil organic matter levels, resulting in improved pasture productivity. Excessive manure application, however, has resulted in extremely high soil P levels. Much of this pasture land is hilly, and is conducive to surface runoff. Because broiler litter is not incorporated into the soil, $P$ tends to accumulate at the surface and is very vulnerable to surface runoff. The combination of cow-calf and broiler enterprises made good economic sense, particularly in the early years when broiler litter was enhancing pasture productivity. Continuing to apply broiler litter to meet nitrogen $(\mathrm{N})$ requirements of the pasture, however, results in excessive accumulation of soil $\mathrm{P}$. This is not likely to be a sustainable practice because relatively little $\mathrm{P}$ leaves the farm in the form of marketed cattle. Phosphorus represents about $0.75 \%$ of live weight of cattle leaving the farm. If a $250 \mathrm{~kg}$ calf is sold from a cow-calf pair each year, and 0.4 ha of pasture and hay ground is needed to support the pair for the year, then only $4.7 \mathrm{~kg} \mathrm{P} \mathrm{ha}^{-1}$ can be added annually if equilibrium is to be maintained. This does not accommodate much broiler litter.

Grazing dairy cows can create a similar problem. Although significantly more $\mathbf{P}$ leaves the farm in milk shipments than in the sale of feeder calves, dairy cows are supplemented with much more grain and protein supplement, and these supplements bring in considerable $\mathrm{P}$. If the paddocks are not periodically rotated into crop production, P slowly builds up in the paddocks. If $25 \%$ of feed $\mathrm{P}$ ends up in milk, and the outside supplements, that is, grain, protein, and occasionally some forage, provide 40 to $50 \%$ of dietary $P$, then the permanent paddocks will experience gradual accumulation of $P$ in the soil. One way of preventing this is to divert some of the manure to other crop land. In The Netherlands, nighttime confinement of dairy cows is sometimes practiced so the manure can be collected and directed to crop land. Although there are environmental advantages with grazing cattle, such as reduced soil erosion due to maintenance of continuous soil cover, extensive use of diet supplements can present challenges to nutrient management, particularly with regard to soil $\mathbf{P}$ buildup and loss.

While much remains to be learned about the relationship between soil P levels and potential threat to surface water quality, increasing levels of soil $P$ in ex- 
cess of crop or grass requirements is known to increase the risk of $\mathrm{P}$ loss in runoff and environmental damage (Sharpley, 1996).

In Europe, legislative controls on reducing $P$ inputs are aimed at either (i) limiting the number of dairy cows a farm can keep based on the cropland area available for manure application, and/or (ii) limiting the amount of manure $P$ that can be land applied (Table 19-6). The Netherlands has adopted the Mineral Accounting System (MINAS) whereby farmers are required to keep records of nutrient inputs and outputs. Taxes are levied on the amount of nutrient surplus that exceed legal limits (Aarts, 2000). Permissible P surplus for croplands for the Year 2000 have been set at $15 \mathrm{~kg} \mathrm{ha}^{-1}$ and will decline to $9 \mathrm{~kg} \mathrm{ha}^{-1}$ by 2008 (Van den Brandt and Smit, 1998). In Wisconsin, $P$ surplus of 3 to $13 \mathrm{~kg} \mathrm{ha}^{-1}$ due to dairy manure applications have been calculated (Powell et al., 2002). On these soil types, surplus $\mathrm{P}$ applications of approximately $9 \mathrm{~kg} \mathrm{ha}^{-1}$ increases soil test $\mathrm{P}$ (Bray-1 extraction) by $1 \mathrm{mg} \mathrm{kg}^{-1}$ (Kelling et al., 1998).

Many of the current environmental problems facing animal agriculture are due to the separation of livestock production from its feed supply (Lanyon and Thompson, 1996). While this is generally true for large swine and poultry operations that import almost all feed, many small dairy operations, especially in the Northeastern and Midwestern regions of the USA, continue to be land-based, that is, they raise most of their feed and recycle manure through cropland. For example, in Wisconsin, most dairy farms have stocking rates of $<1.1$ cows ha ${ }^{-1}$, the threshold value for self-sufficiency in forage (hay plus silage) and grain production (Powell et al., 2002). Self-sufficiency in forage and grain production generally means that a farm has adequate land to recycle its manure $P$ through crops. Whereas a farm can attain self-sufficiency in forage and grain production up to a stocking rate of approximately 1.1 cows ha ${ }^{-1}$, all manure $P$ could potentially be recycled through cropland up to a stocking rate of 1.4 cows ha- ${ }^{-1}$.

Linking the number of animals to the area of land and cropping system available for manure utilization is critical to proper manure management. This is a particular challenge for large dairy operations or beef feedlots where feed is often grown at a distant location. However, it is entirely possible that a large cat-

Table 19-6. Legislative permissible stocking rates and manure application rates in Europe compared to Wisconsin dairy farms. $\dagger$

\begin{tabular}{|c|c|c|c|c|}
\hline Location & Year & Crops & $\begin{array}{l}\text { Stocking rate } \\
\text { cows ha }{ }^{-1}\end{array}$ & $\begin{array}{c}\text { Manure P } \\
\mathrm{kg} \mathrm{ha}^{-1} \mathrm{yr}^{-1}\end{array}$ \\
\hline Norway & 1989 & All & 2.5 & 36 \\
\hline Sweden & 1995 & All & 1.6 & 23 \\
\hline Denmark & 1993 & All & 2.3 & 33 \\
\hline \multirow[t]{2}{*}{ France } & 1991 & Arable & - & 23 \\
\hline & & Grassland & - & 40 \\
\hline \multirow[t]{2}{*}{ Germany } & 1991 & Maize & - & 19 \\
\hline & & Grassland & - & 26 \\
\hline Wisconsin $\ddagger$ & 1999 & All & 1.1 & 21 \\
\hline
\end{tabular}

$\dagger$ European data compiled by Sibbesen and Runge-Metzger (1995).

¥ Wisconsin data from Powell et al. (2002). Data presented for comparative purposes only. No legislation regarding stocking rates exist in Wisconsin. 
tle operation could be placed within reasonable distance of land used for producing feed as well as receiving manure. Klopfenstein and Erickson (2002) describe a situation where a feedlot with 50000 animal capacity feeds more than 5 million bushels of corn $\mathrm{yr}^{-1}$. The land required for growing this amount of corn would be about 12000 ha. This could be situated within a $7 \mathrm{~km}$ radius of the feedlot. At this distance, manure from the feedlot could be readily returned to fields. Whether $\mathrm{P}$ balance could be maintained on the crop acres would depend upon the $\mathrm{P}$ content of other ingredients in the feedlot diet. Since feedlot cattle consume less feed and require a lower density of both $\mathrm{N}$ and $\mathrm{P}$ in the diet than dairy cows, higher stocking rates are possible with feedlot cattle than dairy cattle.

Another challenge facing beef feedlot operations is where large amounts of corn by-products are fed. The number of ethanol plants using corn as feedstock is increasing in the USA, and large amounts of the distiller's grain by-product is fed to feedlot cattle. If a feedlot is nested with farms producing corn for an ethanol plant, and the by-product from ethanol production supplies $40 \%$ of the feedlot diet, then approximately $75 \%$ of the corn grown in the area would go to the ethanol plant and 25\% directly to the feedlot (Klopfenstein and Erickson, 2002). Acreage needed to supply corn for both the ethanol plant and the feedlot would approximately double under this scenario compared to feeding all of the corn directly in the feedlot. The land available for spreading manure also doubles, but the distance traveled to reach outlying fields would not double. The increase in distance would be about $1.6 \mathrm{~km}$. The added cost of transporting manure this distance would be approximately $\$ 0.20$ a ton of feedlot manure. One animal produces about one ton of manure each year, so the cost to the feedlot would be $\$ 0.20$ per animal. Of course this cost would increase if $<100 \%$ of the land were tillable and available for accepting manure under such a plan. Alliances between grain farmers and cattle feeders will need to be developed if the nutrients in feedlot manure are to be recycled through crops and not cause environmental damage.

Although cow/cropland ratios recognize that soils and their associated cropping systems have a limited capacity to recycle manure nutrients, in practice the impact of stocking rates depends on animal parameters, such as feed inputs, milk and manure outputs, and cropland characteristics that affect a field's ability to effectively recycle manure nutrients. For example, dairy farms that feed recommended levels of dietary P produce less manure P (Table 19-5), and therefore, can support more cows per cultivated area than farms that feed excessive P. At similar stocking rates, farms on sloping land and close to surface waters pose a much greater threat to water quality than, for example, farms situated on parts of the landscape less susceptible to runoff. On many dairy farms, the P problem originates not so much from excessive stocking rates but rather from a combination of high dietary $P$ levels and inadequate utilization of available cropland for manure spreading. Farms that have adequate levels of dietary $P$, and use all of their available cropland for manure disposal, can maintain higher stocking rates without increasing $\mathrm{P}$ losses compared to farms that feed $\mathrm{P}$ excessively and spread manure on only parts of their cropland.

Balancing $P$ inputs and outputs through proper feed, fertilizer, and manure management is the first step towards reducing soil $\mathrm{P}$ buildup and $\mathrm{P}$ runoff losses from livestock farms. Various options are available for achieving $\mathrm{P}$ balance. Per- 
haps the most immediate and greatest positive impact would come from reductions in the importation of unnecessary P fertilizer and diet supplements. Few cattle and dairy producers and their nutrient management consultants consider the whole-farm nutrient package and how this may be managed more efficiently to increase profits and conform to nutrient management regulations.

Agricultural management options to reduce $P$ losses to the environment generally attempt to minimize P imports onto the farm while controlling surface runoff and erosion. Many dairy farms and beef feedlot operations consistently accumulate $\mathrm{P}$ because imports of $\mathrm{P}$ in the form of feed and fertilizer simply exceed exports in the form of milk, cattle, and surplus grain or hay (Klausner, 1995; Satter and $\mathrm{Wu}, 1999$ ). However, while a whole-farm nutrient balance is often used as an indicator of a farm's propensity to accumulate and lose nutrients, it may not be a reliable indicator of other performance features. For example, just as there can be profitable dairy operations with excess $P$ accumulation, there can be failing farm dairy operations with balanced nutrient flows.

\section{REFERENCES}

Aarts, H.F.M. 2000. Resource management in a "De Marke" Dairy Farm. Report "De Marke" no. 26. Res. Inst. for Animal Husbandry, P.O. Box 2176, 8203 AD Lelystad, The Netherlands.

Agricultural and Food Research Council. 1991. Technical committee on responses to nutrients. Rep. 6. A reappraisal of the calcium and phosphorus requirement of sheep and cattle. Nutr. Abstr. Rev. (Ser. B) 61:573-612.

Aguerre, M.J., S. Marcot, H. Henselmeyer, and L.D. Satter. 2002. Availability of phosphorus in dairy feeds. J. Dairy Sci. 85(Suppl. 1): 187.

Berger, L.L. 1995. Why do we need a new NRC data base? Anim. Feed Sci. Technol. 53:99-107.

Bertrand, J.A., J.C. Fleck, and J.C. McConnell, Jr. 1999. Phosphorus intake and excretion on South Carolina Dairy Farms. Prof. Anim. Sci. 15:264-267.

Breves, G., and B. Schroder. 1991. Comparative aspects of gastrointestinal phosphorus metabolism. Nutr. Res. Rev. 4:125-140.

Brintrup, R., T. Mooren, U. Meyer, H. Spiekers, and E. Pfeffer. 1993. Effects of two levels of phosphorus intake on performance and fecal phosphorus excretion of dairy cows. J. Anim. Physiol. Anim. Nutr. 69:29-36.

Bundy, L.G. 1998. A phosphorus budget for Wisconsin cropland. A report submitted to the Wisconsin Dep. of Natural Resources and Dep. of Agriculture, Trade and Consumer Protection. Univ. of Wisconsin, Madison.

Call, J.W., J.E. Butcher, J.T. Blake, R.A. Smart, and J.L. Shupe. 1978. Phosphorus infuence on growth and reproduction of beef cattle. J. Anim. Sci. 47:216-225.

Combs S.M., and J.B. Peters. 2000. Wisconsin soil test summary: 1995-99. New Horizons in Soil Science. no. 8. Dep. of Soil Science, Univ. of Wisconsin, Madison.

Dou, Z., K.F. Knowlton, R.A. Kohn, Z. Wu, L.D. Satter, G. Zhang, J.D. Toth, and J.D. Ferguson. 2002. Phosphorus characteristics of dairy feces affected by diets. J. Environ. Qual. 31:2058-2065.

Durand, M., and R. Kawashima. 1980. Influence of minerals in rumen microbial digestion. p. 375408. In Y. Ruckebusch and P. Thivend (ed.) Digestive physiology and metabolism in ruminants. MTP Press, Lancaster, England.

Durand, M., and S. Komisarczuk. 1988. Influence of major minerals on rument microbiota. J. Nutr. $118: 249-260$.

Ebeling, A.M., L.G. Bundy, J.M. Powell, and T.W. Andraski. 2002. Dairy diet phosphorus effects on phosphorus losses in runoff from land-applied manure. Soil Sci. Soc. Am. J. 66:284-291.

Ellenberger, H.G., J.A. Newlander, and C.H. Jones. 1950. Composition of the bodies of dairy cattle. Bull. 558. Vt. Agric. Exp. Stn., Burlington.

Erickson, G.E., T.J. Klopfenstein, C.T. Milton, D. Brink, M.W. Orth, and K.M. Whittet. 2002. Phosphorus requirement of finishing feedlot calves. J. Anim. Sci. 80:1690-1695. 
Erickson, G.E., T.J. Klopfenstein, C.T. Milton, D. Hanson, and C. Calkins. 1999. Effect of dietary phosphorus on finishing steer performance, bone status, and carcass maturity. J. Anim. Sci. 77:2832-2836.

Hignett, S.L. and P.G. Hignett. 1951. The influence of nutrition on reproductive efficiency in cattle. I. The effect of calcium and phosphorus intake on the fertility of cows and heifers. In: C.L. Comar and F. Bonner (eds) Vet Rec. 63: 603-609.

Judkins, M.B., J.D. Wallace, E.E. Parker, and J.D. Wright. 1985. Performance and phosphorus status of range cows with and without phosphorus supplementation. J. Range Manage. 38:139-143.

Karn, J.F. 2001. Phosphorus nutrition of grazing cattle: a review. Animal Feed Sci. Technol. 38:133153.

Kelling, K.A., L.G. Bundy, S.M. Combs, and J.B. Peters. 1998. Soil test recommendations for field, vegetable and fruit crops. Rep. A2809. Univ. of Wisconsin Coop. Ext., Madison.

Kincaid, R.L., J.K. Hillers, and J.D. Cronrath. 1981. Calcium and phosphorus supplementation of rations for lactating cows. J. Dairy Sci. 64:754-758.

Klausner, S. 1995. Nutrient management planning. p. 383-391. In K. Steele (ed) Animal waste and the land-water interphase.Lewis Publ., New York.

Klopfenstein, T.J., and G.E. Erickson. 2002. Effects of manipulating protein and phosphorus nutrition of feedlot cattle on nutrient management and the environment. J. Anim. Sci. 80 (E. Suppl. 2): E106-E114.

Lanyon, L.E., and P.B. Thompson. 1996. Changing emphasis on farm production. In Animal agriculture and the environment: Nutrients, pathogens, and community relations. p. 15-23. Proc. from the Animal Agriculture and the Environment North American Conf., Rochester, NY. 11-13 December. Northeast Regional Agric. Eng. Serv., Ithaca, NY.

Little, D.A. 1980. Observations on the phosphorus requirement of cattle for growth. Res. Vet. Sci. 28 : 258-268

Lopez, H., F.D. Kanitz, V.R. Moreira, M.C. Wiltbank, and L.D. Satter. 2002. Effect of dietary phosphorus concentration on reproductive performance of lactating dairy cows. J. Dairy Sci. 85(Suppl.1):364 (Abstr.).

NRC. 1989. Nutrient requirements of dairy cattle. 6th ed. Natl. Academy Press, Washington, DC.

NRC. 1996. Nutrient requirements of beef cattle. 7th ed. Natl. Academy Press, Washington, DC.

NRC. 2001. Nutrient requirements of dairy cattle. 7th ed. Natl. Academy Press, Washington, DC.

Powell, J.M., D. Jackson-Smith, and L.D. Satter. 2002. Phosphorus feeding and manure recycling on Wisconsin dairy farms. Nutrient Cycl. Agroecosyst. 62:277-286.

Powell J.M., Z. Wu, and L.D. Satter. 2001. Dairy diet effects on phosphorus cycles of cropland. J. Soil Water Conserv. 56 (1):22-26.

Proost, R.T. 1999. Variability of P and K soils test levels on Wisconsin Farms. p. 278-282. In Proc. of the 1999 Wisconsin Fertilizer, Aglime \& Pest Manage. Conf., Madison WI. 19-21 Jan.1999. Univ. of Wisconsin-Extension, Madison.

Reed, W.D.C., R.C. Elliott, and J.H. Topps. 1965. Phosphorus excretion of cattle fed on high-energy diets. Nature (London) 208:953-954.

Sansinena, M., L.D. Bunting, S.R. Stokes, and E.R. Jordan. 1999. A survey of trends and rationales for phosphorus recommendations among Mid-South nutritionists. p. 51-54. In Proc. Mid-South Ruminant Nutr. Conf., Dallas, TX. Texas A\&M Univ., College Station.

Satter, L.D., and T.R. Dhiman. 1996. Formulating dairy diets: Enhancing profitability and reducing environment impact. p. 93-101. In Proc. of the Dairy Forage Res. Center Conf. with Dairy and forage Industries, Madison, WI. U.S. Dairy Forage Res. Ctr., USDA-ARS, Madison.

Satter, L.D., and Z. Wu. 1999. Reducing manure phosphorus by dairy diet manipulation. p. 183-192. In Proc. of the 1999 Wisconsin Fertilizer, Aglime \& Pest Manage. Conf., Madison WI. 19-21 Jan.1999.

Satter, L.D., and Z.Wu. 2000. Balancing the animals' nutritional needs with environmental stewardship. Adv. Dairy Technol. 12:43-57.

Sharpley, A.N. 1996. Myths about phosphorus. p. 60-75. In Animal agriculture and the environment. Proc. Animal Agriculture and the Environment Conf., Rochester, NY. December 1996. Northeast Regional Agric. Eng. Serv., Coop. Ext., Ithaca, NY.

Sibbesen E., and A. Runge-Metzger. 1995. Phosphorus balance in European agriculture-status and policy options. p. 43-57. In $\mathrm{H}$. Tiessen (ed) Phosphorus in the global environment. John Wiley \& Sons, New York.

Tamminga, S. 1992. Nutrition management of dairy cows as a contribution to pollution control. J. Dairy Sci. 75:345-357.

Ternouth, J.H. 1990. Phosphorus and beef production in northern Australia. 3. Phosphorus in cattlea review. Trop. Grassl. 24:159-169. 
Theiler, A., and H.H. Green. 1932. Aphosphorosis in ruminants. Nutr. Abstr. Rev. 1:359-385.

U.S. Department of Agriculture-Natural Resources Conservation Service. 2001. Conservation practice standard, nutrient management. CODE 590, Part 402. NRCS, Washington, DC.

Valk, H., and L.B.J. Sebek. 1999. Influence of prolonged feeding of limited amounts of phosphorus on dry matter intake, milk production, reproduction and body weight of dairy cows. J. Dairy Sci. 82:2157-2163.

Van den Brandt, H.P., and H.P. Smit. 1998. Mineral accounting: A way to combat eutrophication and to achieve the drinking water objective. Environ. Pollut. 102:705-709.

Wu, Z., and L.D. Satter. 2000. Milk production and reproductive performance of dairy cows fed two concentrations of phosphorus for two years. J. Dairy Sci. 83:1052-1063.

Wu, Z., L.D. Satter, A.J. Blohowiak, R.H. Stauffacher, and J.H. Wilson. 2001. Milk production, estimated phosphorus excretion, and bone characteristics of dairy cows fed different amounts of phosphorus for two or three years. J. Dairy Sci. 84:1738-1748.

Wu, Z., L.D. Satter, and R. Sojo. 2000. Milk production, reproductive performance, and fecal excretion of phosphorus by dairy cows fed three amounts of phosphorus. J. Dairy Sci. 83:1028-1041. 